\title{
Review
}

Molecular

Neuropsychiatry
Mol Neuropsychiatry 2015;1:156-164

DOI: $10.1159 / 000439085$
Received: July 2, 2015

Accepted: July 29, 2015

Published online: September 4, 2015

\section{Tourette Syndrome: Bridging the Gap between Genetics and Biology}

\author{
Petra Richer ${ }^{\mathrm{a}}$ Thomas V. Fernandez ${ }^{\mathrm{b}}$ \\ a The University of the South, Sewanee, Tenn., and ${ }^{b}$ Yale Child Study Center and Department of Psychiatry, \\ Yale University School of Medicine, New Haven, Conn., USA
}

\section{Key Words}

Common variant . Copy number variation - Dopamine .

Genetics - Genome-wide association study · Glutamate .

Histamine · Linkage analysis · Neurotransmitters · Rare

variant

\begin{abstract}
Tourette syndrome is a childhood neuropsychiatric disorder, which presents with disruptive motor and vocal tics. The disease also has a high comorbidity with obsessive-compulsive disorder and attention deficit hyperactivity disorder, which may further increase the distress experienced by patients. Current treatments act with varying efficacies in alleviating symptoms, as the underlying biology of the disease is not fully understood to provide precise therapeutic targets. Moreover, the genetic complexity of the disorder presents a substantial challenge to the identification of genetic alterations that contribute to the Tourette phenotype. Nevertheless, genetic studies have suggested involvement of dopaminergic, serotonergic, glutamatergic, and histaminergic pathways in the pathophysiology of at least some cases. In addition, genetic overlaps with other neuropsychiatric disorders may point toward a shared biology. The findings that
\end{abstract}

are emerging from genetic studies will allow researchers to piece together the underlying components of the disease in the hopes that a deeper understanding of Tourette syndrome can lead to improved treatments for those affected by it.

(c) 2015 S. Karger AG, Base

\section{Introduction}

Tourette syndrome (TS) is a neuropsychiatric disorder characterized by combinations of motor and vocal tics that persist for longer than 1 year [1]. The presentation of motor tics can be categorized as either simple or complex, with simple tics generally involving only one muscle group, such as blinking or twitching of the nose $[2,3]$. Complex tics tend to require multiple muscle groups and can be a sequence of movements or a combination of simple tics [2]. Examples include grimacing combined with twisting of the head, kicking, or spinning around [3]. Vocal tics often arise after the onset of motor tics and can also be divided into simple and complex [3]. Simple vocal tics are the production of various sounds and noises, such as throat clearing, coughing, or sniffing [3]. Complex vo-

\section{KARGER 125}

E-Mail karger@karger.com www.karger.com/mnp (c) 2015 S. Karger AG, Base

2296-9209/15/0013-0156\$39.50/0
Thomas V. Fernandez, MD

Yale Child Study Center

230 South Frontage Road

New Haven, CT 06520 (USA)

E-Mail thomas.fernandez@yale.edu 
cal tics, on the other hand, can be linguistically meaningful, including phenomena such as echolalia, palilalia, and coprolalia [2].

Many patients report a premonitory urge that is present before the occurrence of a tic, followed by a sense of relief as soon as the tic is performed; however, this is usually temporary $[2,4]$. Moreover, tics will present in a waxing and waning fashion, exacerbated in periods of anxiety, stress, excitement, or anger, and decreasing or ceasing during sleep, rest, or concentration [2]. Age also appears to be a determinant of severity, since tic prevalence tends to decrease from childhood to adolescence and early adulthood [5].

In the general population, $0.5-0.7 \%$ of people are affected by TS at some point in their lives, with a greater prevalence in males than females $(\sim 3: 1)[6,7]$. The median age of onset among children is 6 years, and tics reach the peak of their severity at approximately $10.6 \pm 2.6$ years of age $[5,8]$. Twin studies have found a concordance rate of $53 \%$ in monozygotic and $8 \%$ in dizygotic twins, indicating a substantial genetic component to the disease [9]. In addition to tics, people with TS can also be affected by other comorbidities [8]. The lifetime prevalence of at least one other psychiatric disorder with TS is near $85 \%$, with obsessive-compulsive disorder (OCD) and attention deficit hyperactivity disorder being the most common [8]. There is evidence that these conditions are genetically correlated, since about $20 \%$ of patients with TS also suffer from OCD or attention deficit hyperactivity disorder, rates that are much higher than the population prevalence [8]. The percentage of individuals with all three disorders is even higher, at around 30\% [8]. While tics themselves may be sufficient to impact quality of life, comorbid conditions can further increase strain on relationships, academic achievement, self-esteem, as well as social interactions [4].

Current treatment options for TS vary in effectiveness among individuals and include behavioral therapy and various medications for controlling disruptive tics [10, 11]. Behavioral therapy has been demonstrated to be effective in decreasing tic severity in both the presence and absence of medications [12]. In Comprehensive Behavioral Intervention for Tics therapy, awareness training is utilized to teach patients how to recognize premonitory urges that precede tics [10]. Competing-response training instructs patients to complete a different voluntary action in the place of the tic, while relaxation training is used to address stress and anxiety, which may have an impact on the frequency and intensity of tic occurrence [10]. Available drugs include typical (e.g. haloperidol) and atypical (e.g. risperidone) antipsychotics and $\alpha_{2}$ adrenergic agonists (e.g. clonidine and guanfacine) [3] These medications act with varying efficacies, and many have detrimental side effects such as sedation, weight gain, dyskinesia, or cognitive blunting [3,13-19]. The remaining questions about TS pathophysiology and a need for new and improved treatment options has prompted the study of genetic causes that underlie the disease in the hopes of identifying novel therapeutic targets and increasing our understanding of this complex disorder.

\section{Progression of Genetic Studies}

It is now widely accepted that TS has a heterogeneous genetic architecture, where multiple genes likely contribute to disease development and pathogenesis; however, the assumption that a single gene controls the tic phenotype was a pitfall of many early genetic studies [20]. Linkage studies were among the first to investigate the genetic cause of TS by identifying and studying families where the disease was present in multiple members, in the hopes of pinpointing certain alleles that may be linked to the symptoms [21]. Parametric linkage studies were conducted on the premise that TS is inherited in an autosomal dominant fashion, where mutations in a specific gene result in the development of the disease [22]. Numerous studies examined TS-affected families spanning multiple generations; however, no specific locus was confirmed, and the findings demonstrated that TS is a genetically complex disorder [23-29].

Nonparametric linkage studies take into account the heterogeneity of TS and the possible interplay of environmental risk factors [30,31]. Several studies have used this approach and have identified multiple potential loci [3238]. However, there has not been overlap in a specific genomic region, indicating that different approaches and larger sample sizes may be required to identify risk genes [39].

Thus far, one causative mutation has been found using the single-pedigree analysis method, where Ercan-Sencicek et al. [40] performed linkage analysis in a family where the father and all 8 children were diagnosed with TS, suggesting a dominant mode of transmission and high penetrance. All affected family members had current or past motor and vocal tics, and 8 had current or past vocal tics; all shared the same allele on chromosome 15 , harboring a heterozygous nonsense point mutation (W317X) at nucleotide position 951 in exon 9 of the gene HDC (histidine decarboxylase), which generated a maxi- 
mum theoretical logarithm of the odds score [40]. The W317X abnormality resulted in a mutant form of the histidine decarboxylase (HDC) enzyme, lacking an essential portion of its active domain, which is responsible for catalyzing the synthesis of histamine from histidine [40]. To date, this mutation has not been found in other TS-affected or -unaffected individuals outside of this family. However, its discovery, for the first time, added histaminergic neurotransmission to the list of possible mechanisms involved in the biology of TS and prompted a clinical trial of an $\mathrm{H} 3$ receptor antagonist, AZD5213, in adolescents with TS (ClinicalTrials.gov ID: NCT01904773); subsequent support for a 'histamine hypothesis' came from a European family-based association study, a study of copy number variation $(\mathrm{CNV})$ in TS [41], and animal models [42-44].

Candidate gene association studies have tested TS cases and control subjects for single nucleotide polymorphisms (SNPs) in candidate genes that are chosen based on hypotheses of plausible biological pathways $[39,45]$. These include dopamine (DA) receptors, transporters, and catabolizing genes, serotonergic genes, and noradrenergic transcripts [46-57]. Although the low cost of examining only a few specific variants is appealing, the a priori probability that these variants will play a role in conferring risk for the disease is low, and sample sizes have generally been inadequate. Consequently, studies to date have produced varying results with nonsignificant or nonreproducible findings $[39,45]$.

Chromosomal abnormalities have been studied to determine which regions of the genome may have alterations as a result of deletions, duplications, translocations, or inversions. Areas affected by these variations can highlight candidate regions and genes to be examined in the context of TS. IMMP2L was implicated in a Danish TS cohort of 188 patients, where Bertelsen et al. [58] identified an increase in small intergenic deletions. Three separate studies also found abnormalities in chromosome $18 \mathrm{q} 22$, where breakpoints near the IMMP2L gene were observed [59-61]. The CNTNAP2 gene was also discovered to have rearrangements in one TS family, while another family had a translocation affecting the gene, but with no symptoms $[62,63]$. CNTNAP2 has also been implicated in autism spectrum disorders (ASD), schizophrenia, and intellectual disability, and it is believed to be involved in ion channel distribution along the axon as well as in interactions between neurons and glial cells [62, 64]. A small, transmitted exonic deletion was observed in NLGN4X, also involved in ASD, in a family with TS, motor tics, autism, learning problems, anxiety, and depres- sion [65-67]. Prontera et al. [68] identified a disrupted locus of DPP6 in a son and father with TS. The gene has also been connected to ASD pathogenesis and neuroleptic-induced dyskinesia.

Lastly, the study of a family with 1 case of TS highlighted a de novo inversion on chromosome 13, which caused a breakpoint at 13q31, $350 \mathrm{~kb}$ away from the gene SLITRK1 (Slit and Trk-like, Family Member 1) [69]. This same study examined 174 unrelated TS patients and found a frameshift mutation, resulting in a truncated protein in 1 TS and 1 trichotillomania patient [69]. Furthermore, this study identified a rare single base pair change, var321, at a regulatory micro-RNA-binding site in the SLITRK1 3' UTR. This finding had a significant association with TS $(p=0.0056)$ [70]. Several subsequent studies have examined the association of SLITRK1 with TS by resequencing probands but did not locate additional pathogenic coding frame mutations in the gene [71-73] or did not find an association for the specific var321 [74, 75]. On the other hand, significant associations have been reported between var321 and TS $[76,77]$ or trichotillomania [78]. These results must be interpreted with caution, as studies examining the association between variants in SLITRK1 and TS to date have been relatively small and generally lacking sufficient power to conclusively confirm or refute an association. Further studies involving much larger TS cohorts and employing the latest genomic technologies will be needed to clarify the contribution of variation in and around SLITRK1 toward TS disease risk.

Little is known about its function; however, SLITRK1 is believed to enhance expression during development to promote axon path finding, while it is also highly expressed in cholinergic neurons of the striatum throughout the lifespan [79]. In vitro studies have determined that SLITRK1 promotes dendritic growth, while dendritic regression results from TS-associated alleles [69]. A SLITRK1 knockout (KO) mouse model presented with anxiety as well as increased noradrenergic activity; however, no tic-like movements were observed [80]. Technological advances and a decline in genotyping costs have allowed studies to better investigate genetic susceptibility to TS across the genome [81]. In contrast to candidate gene association studies, genome-wide association studies (GWAS) do not require preselection of genomic regions, performing individual comparisons to analyze the combined effect size of SNPs on disease susceptibility [45, 82]. However, there is a high genome-wide statistical significance threshold $\left(\mathrm{p}<5 \times 10^{-8}\right)$ to confirm a disease locus due to the large number of comparisons [83]. With 
the modest effect sizes seen for common variants in complex genetic disorders $(\sim 1.1)$, large sample sizes are generally required to achieve a statistically significant signal. The one TS GWAS published to date (1,496 cases and 5,249 controls) has not pinpointed a statistically significant TS locus [83]. However, some sub-threshold GWAS peaks may still signal the involvement of variants fundamental to TS pathophysiology [84]. In the TS GWAS, Scharf et al. [83] found COL27A1 on chromosome 9q32 to have a strong association with TS $\left(\mathrm{p}=1.85 \times 10^{-6}\right)$. Furthermore, Paschou et al. [84] examined a top region from this GWAS in 609 cases and 610 controls and identified a single intergenic SNP (rs2060546) near the gene NTN4 that was associated with TS; this finding remained statistically significant after Bonferroni correction. NTN4 is believed to code for an axon guidance molecule in the developing striatum, an area implicated in TS; however, larger cohorts are required to confirm these findings [84].

The study of CNV has been made practical through the advent of affordable and high-resolution microarray technology, which can detect structural variants in DNA [85]. While CNVs occur in the general population, studies have examined whether the burden of rare and de novo CNVs is greater in individuals with complex disorders, like TS $[86,87]$. Although no significant difference between cases and controls has been reported in TS thus far, the identified CNVs may implicate certain genes in TS. A study conducted by Sundaram et al. [88] examined 111 cases and 73 controls, finding rare recurrent CNVs in NRXN1 and CTNNA3, which are thought to play a role in ASD and schizophrenia. Large CNVs found by Nag et al. [89] in a study of 179 TS patients and 234 controls also highlighted NRXN1 as a possible TS gene, along with COL8A1. Moreover, Fernandez et al. [90] reported disruptions in histamine signaling and GABA receptor genes during an investigation of CNVs in 460 TS and 1,131 control subjects. In addition, a study examining 1,086 TS, $1,613 \mathrm{OCD}$, and 1,789 control subjects detected large deletions at $16 \mathrm{p} 13.11$ for 5 participants; however, the evidence for association was stronger for OCD than TS [91].

More recently, whole-exome and whole-genome nextgeneration sequencing have become increasingly popular options for the study of complex disorders, especially as declining costs allow greater availability for their use in research. Exome sequencing of a 3-generation pedigree with 7 TS-affected members revealed single nucleotide variants in three genes, MRPL3, DNAJC13, and OFCC1, which have not yet been implicated in other studies [92]. Hooper et al. [93] performed whole-genome sequencing on a single individual with TS and comorbid OCD, dis- covering a translocation at $(6 ; 22)(\mathrm{q} 16 ; \mathrm{p} 13)$. This alteration caused a 400-kb deletion in 6q16, affecting GPR64, NDUFA4, and KLHL32 [93]. While these 2 published studies have applied next-generation sequencing in only a small number of patients to date, larger-scale exome sequencing studies in parent-child trios are currently underway. If such studies reveal an increase in de novo mutation burden, similar to findings in autism and schizophrenia, this approach will be very likely to lead toward gene discovery in TS. Such studies can provide insight into how changes in protein-coding and even regulatory regions have an effect on TS risk, leading us toward the ultimate goal of gaining a deeper understanding of the underlying biology to inform interventions with greater efficacies. Thus far, genetic studies have shown some overlap with findings from other research approaches (e.g. brain imaging and pharmacological studies), pointing us toward the involvement of certain neurotransmitter systems and implicating brain regions suspected to be involved in TS pathology.

\section{Pathophysiology}

The cortico-striato-thalamo-cortical circuit has been implicated in the biology of TS due to its involvement in movement initiation and inhibition [94]. The striatum has been a particular region of interest in research, with studies indicating that deficits of striatal pathways contribute to TS etiology [43, 95-100]. A PET study examining 18 TS patients and 16 controls found that the ventral striatum was significantly affected, since the activation of the ventral striatum corresponded with motor cortical area activation in TS patients [100]. On the other hand, healthy individuals demonstrated a negative correlation in activity between the two areas [100]. The aforementioned cortico-striato-thalamo-cortical pathways require various neurotransmitters (glutamate, DA, GABA, and serotonin) for signal transduction, and previous studies have reported abnormalities in these systems in TS [9598, 101-105]. Most recently, the histaminergic pathway has also been added to the list of potentially malfunctioning systems in the disorder $[40,90]$.

Genetic studies in TS are beginning to show agreement with imaging, animal models, and pharmacological findings, and the hope is that these convergences will provide a more complete understanding of TS pathophysiology. The dopaminergic system has been an area of interest since dopamine antagonists (e.g. risperidone, pimozide, and haloperidol) have been used to attenuate 
tics [11]. Singer et al. [97] found an upregulation of DA receptors in the postmortem striatum of TS patients compared to unaffected controls, indicating a decrease in extracellular DA. In addition, studies have detected an association between TS and certain SNPs in the gene encoding the dopamine receptor D2 (DRD2); however, the results are based on small cohorts $[49,103,106]$. Other studies have not been able to find connections between the DA receptor and TS $[107,108]$. Nonetheless, some research examining the dopamine transporter 1 (DAT1) gene (SLC6A3) converge to support its involvement in TS biology, strengthening the view that the dopaminergic system plays a substantial role in the disease $[47,50$, 109].

In the serotonergic pathway, tryptophan hydroxylase (TPH2) has been an interest of study, since it acts as the rate-limiting enzyme in serotonin synthesis [110]. To date, Mössner et al. [56] have identified intronic SNPs (rs4565946, rs4570625) in the TPH2 gene during a study of 98 TS patients and 178 controls. On the other hand, serotonin receptor genes have not been able to provide significant findings and require more extensive study $[111,112]$. Similarly, research focusing on the serotonin transporter (SERT) gene (SLC6A4) has provided varying results $[53,113]$, although a recent finding by Moya et al. [114] highlights the association of a high-expression variant and a rare gain-of-function variant of the gene with TS.

Recently, the glutamatergic pathway has also garnered attention in the understanding of TS biology due to its role in $\mathrm{OCD}$, where malfunctioning neurotransmission of glutamate has been studied [115]. Due to the high comorbidity of TS with OCD, indications for a shared genetic and pathophysiological background have been examined. SLC1A3 (Solute Carrier, Family 1, Member 3), a gene related to a supported OCD candidate gene (SLC1A1), was investigated by Adamczyk et al. [116] in the context of TS. Although a functional missense variant was overrepresented in affected individuals, it was not statistically significantly different from controls [116]. In addition, the SAP90/PSD95-associated protein 3 (SAPAP3/DLGAP3), involved in synaptic scaffolding, has been a candidate area of research, as it is present in the glutamatergic synapses of the striatum [117]. As a result, Crane et al. [117] studied 289 TS trios and determined a nominally significant genetic association between DLGAP3 and TS. Moreover, DLGAP3/SAPAP3 KO mice have demonstrated OCD-like behaviors, such as compulsive grooming and anxiety, along with excitatory synaptic dysfunction in the striatum $[118,119]$.
The findings of Ercan-Sencicek et al. [40] on HDC shed light on the involvement of the histaminergic pathway in TS etiology and its connection to the disease phenotype. Histamine is normally involved in smooth muscle contractions and neurotransmission; however, disturbances in its synthesis by HDC can have detrimental effects [120]. Ohtsu et al. [121] examined HDC KO mice and found that they exhibited a 50\% decrease in brain histamine levels, reinforcing the enzyme's role in histamine synthesis. A more recent HDC KO mouse model also observed a decrease in histamine, but also discerned an increase in DA, along with elevated D2 and D3 receptor density in the substantia nigra [42]. Additionally, increased motor stereotypies were observed with the $\mathrm{KO}$ mice, which could be diminished through the administration of haloperidol, a D2 agonist [42]. Individuals affected with the W317X mutation, which causes the production of an abnormal HDC, also present with an increase in D2 and D3 receptors in the same region [42]. These new findings suggest novel therapeutic approaches to treat the disorder, while reinforcing the importance of genetic studies in elucidating the underlying mechanisms that characterize TS.

\section{Discussion and Future Directions}

The intricate phenotype and biological mechanisms underlying TS, along with the need for treatments with greater efficacy, have been an impetus for understanding the genetic basis of the disease. In retrospect, early studies did not adequately account for the genetic complexity of TS, and its heterogeneity is becoming evident as research in the field progresses. Nevertheless, some studies are beginning to strengthen support for the involvement of dopaminergic, glutamatergic, and serotonergic systems in the pathophysiology of TS. Most recently, the histaminergic pathway has been included as a new target of research and, possibly, treatment. The genetic overlap between TS and other neuropsychiatric disorders, most notably ASD, may also shed light on shared mechanisms amongst the diseases [88, 90, 91]. For the most part, many genetic findings in TS to date have not reached statistical significance or lack reproducibility. Studies now underway seek to utilize larger cohorts and high-throughput sequencing to garner support for specific genes and biological pathways in TS [122-124]. There is great hope that these new studies will accelerate progress in understanding TS so that we can improve the lives of those suffering from this debilitating disorder. 


\section{Acknowledgements}

Research reported in this publication was supported by the $\mathrm{Na}$ tional Institute of Mental Health of the National Institutes of Health under Award Number K08MH099424 (TVF). The content is solely the responsibility of the authors and does not necessarily represent the official views of the National Institutes of Health.

\section{Statement of Ethics}

The authors have no ethical conflicts to disclose.

\section{Disclosure Statement}

T.V.F. receives research funding from National Institute of Mental Health (NIMH), the Simons Foundation, Allison Family Foundation, and Shire. P.R. has no disclosures.

\section{References}

1 Scharf JM, Miller LL, Mathews CA, Ben-Shlomo Y: Prevalence of Tourette syndrome and chronic tics in the population-based Avon longitudinal study of parents and children cohort. J Am Acad Child Adolesc Psychiatry 2012;51:192-201.e5.

$\checkmark 2$ Singer HS: Tourette's syndrome: from behaviour to biology. Lancet Neurol 2005;4:149159.

3 Tallur K, Minns RA: Tourette's syndrome. Paediatr Child Health 2010;20:88-93.

4 Leckman JF: Tourette's syndrome. Lancet 2002;360:1577-1586.

5 Bloch MH, Peterson BS, Scahill L, Otka J, Katsovich L, Zhang H, et al: Adulthood outcome of tic and obsessive-compulsive symptom severity in children with Tourette syndrome. Arch Pediatr Adolesc Med 2006;160: 65-69.

6 Scahill L, Dalsgaard S, Bradbury K: The prevalence of Tourette syndrome and its relationship to clinical features; in Martino D, Leckman JF (eds): Tourette Syndrome. Oxford, Oxford University Press, 2013, pp 121-133.

7 Robertson MM: The Gilles de la Tourette syndrome: the current status. Arch Dis Child Educ Pract Ed 2012;97:166-175.

8 Hirschtritt ME, Lee PC, Pauls DL, Dion Y, Grados MA, Illmann C, et al: Lifetime prevalence, age of risk, and genetic relationships of comorbid psychiatric disorders in Tourette syndrome. JAMA Psychiatry 2015;72:325333.

$\checkmark 9$ Price RA, Kidd KK, Cohen DJ, Pauls DL, Leckman JF: A twin study of Tourette syndrome. Arch Gen Psychiatry 1985;42:815820 .

10 Piacentini J, Woods DW, Scahill L, Wilhelm $S$, Peterson AL, Chang S, et al: Behavior therapy for children with Tourette disorder: a randomized controlled trial. JAMA 2010;303: 1929-1937.

11 Shprecher D, Kurlan R: The management of tics. Mov Disord 2009;24:15-24.

-12 O'Connor KP, Laverdure A, Taillon A, Stip E, Borgeat F, Lavoie M: Cognitive behavioral management of Tourette's syndrome and chronic tic disorder in medicated and unmedicated samples. Behav Res Ther 2009;47 1090-1095.
13 Gaffney GR, Perry PJ, Lund BC, Bever-Stille KA, Arndt S, Kuperman S: Risperidone versus clonidine in the treatment of children and adolescents with Tourette's syndrome. J Am Acad Child Adolesc Psychiatry 2002;41:330336.

14 Dion Y, Annable L, Sandor P, Chouinard G: Risperidone in the treatment of Tourette syndrome: a double-blind, placebo-controlled trial. J Clin Psychopharmacol 2002;22:31-39.

15 Scahill L, Chappell PB, Kim YS, Schultz RT, Katsovich L, Shepherd E, et al: A placebo-controlled study of guanfacine in the treatment of children with tic disorders and attention deficit hyperactivity disorder. Am J Psychiatry 2001;158:1067-1074.

16 Shapiro E, Shapiro AK, Fulop G, Hubbard M, Mandeli J, Nordlie J, et al: Controlled study of haloperidol, pimozide and placebo for the treatment of Gilles de la Tourette's syndrome. Arch Gen Psychiatry 1989;46:722-730.

17 Ross MS, Moldofsky H: A comparison of pimozide and haloperidol in the treatment of Gilles de la Tourette's syndrome. Am J Psychiatry $1978 ; 135: 585-587$.

18 Singer HS, Gammon K, Quaskey S: Haloperidol, fluphenazine and clonidine in Tourette syndrome: controversies in treatment. Pediatr Neurosci 1985;12:71-74.

19 Cummings DD, Singer HS, Krieger M, Miller TL, Mahone EM: Neuropsychiatric effects of guanfacine in children with mild Tourette syndrome: a pilot study. Clin Neuropharmacol 2002;25:325-332.

20 Krystal JH, State MW: Psychiatric disorders: diagnosis to therapy. Cell 2014;157:201-214.

21 Walkup JT, LaBuda MC, Singer HS, Brown J, Riddle MA, Hurko O: Family study and segregation analysis of Tourette syndrome: evidence for a mixed model of inheritance. Am J Hum Genet 1996;59:684-693.

22 Pauls DL, Leckman JF: The inheritance of Gilles de la Tourette's syndrome and associated behaviors. Evidence for autosomal dominant transmission. N Engl J Med 1986;315: 993-997.

23 Barr CL, Wigg KG, Pakstis AJ, Kurlan R, Pauls D, Kidd KK, et al: Genome scan for linkage to Gilles de la Tourette syndrome. Am J Med Genet 1999;88:437-445.
24 Curtis D, Robertson MM, Gurling HM: Autosomal dominant gene transmission in a large kindred with Gilles de la Tourette syndrome. Br J Psychiatry 1992;160:845-849.

25 Heutink P, van de Wetering BJ, Breedveld GJ Oostra BA: Genetic study on Tourette syndrome in the Netherlands. Adv Neurol 1992; 58:167-172.

26 McMahon WM, Leppert M, Filloux F, van de Wetering BJ, Hasstedt S: Tourette symptoms in 161 related family members. Adv Neurol 1992;58:159-165.

27 Pakstis AJ, Heutink P, Pauls DL, Kurlan R, van de Wetering BJ, Leckman JF, et al: Progress in the search for genetic linkage with Tourette syndrome: an exclusion map covering more than $50 \%$ of the autosomal genome. Am J Hum Genet 1991;48:281-294.

28 Pauls DL, Pakstis AJ, Kurlan R, Kidd KK, Leckman JF, Cohen DJ, et al: Segregation and linkage analyses of Tourette's syndrome and related disorders. J Am Acad Child Adolesc Psychiatry 1990;29:195-203.

29 Verkerk AJ, Cath DC, van der Linde HC, Both J, Heutink P, Breedveld G, et al: Genetic and clinical analysis of a large Dutch Gilles de la Tourette family. Mol Psychiatry 2006;11:954964.

30 Hasstedt SJ, Leppert M, Filloux F, van de Wetering BJ, McMahon WM: Intermediate inheritance of Tourette syndrome, assuming assortative mating. Am J Hum Genet 1995;57: 682-689.

31 Seuchter SA, Hebebrand J, Klug B, Knapp M, Lehmkuhl G, Poustka F, et al: Complex segregation analysis of families ascertained through Gilles de la Tourette syndrome. Genet Epidemiol 2000; 18:33-47.

-32 Tourette Syndrome Association International Consortium for Genetics: Genome scan for Tourette disorder in affected-sibling-pair and multigenerational families. Am J Hum Genet 2007;80:265-272.

-33 A complete genome screen in sib pairs affected by Gilles de la Tourette syndrome. The Tourette Syndrome Association International Consortium for Genetics. Am J Hum Genet 1999;65:1428-1436. 
>34 Zhang H, Leckman JF, Pauls DL, Tsai CP, Kidd KK, Campos MR, et al: Genomewide scan of hoarding in sib pairs in which both sibs have Gilles de la Tourette syndrome. Am J Hum Genet 2002;70:896-904.

- 35 Kroisel PM, Petek E, Emberger W, Windpassinger C, Wladika W, Wagner K: Candidate region for Gilles de la Tourette syndrome at 7q31. Am J Med Genet 2001;101:259-261.

-36 Miranda DM, Wigg K, Feng Y, Sandor P, Barr CL: Association study between Gilles de la Tourette syndrome and two genes in the Robo-Slit pathway located in the chromosome 11q24 linked/associated region. Am J Med Genet B Neuropsychiatr Genet 2008;147B:6872.

37 Paschou P, Feng Y, Pakstis AJ, Speed WC, DeMille MM, Kidd JR, et al: Indications of linkage and association of Gilles de la Tourette syndrome in two independent family samples: $17 \mathrm{q} 25$ is a putative susceptibility region. Am J Hum Genet 2004;75:545-560.

-38 Curtis D, Brett P, Dearlove AM, McQuillin A, Kalsi G, Robertson MM, et al: Genome scan of Tourette syndrome in a single large pedigree shows some support for linkage to regions of chromosomes 5, 10 and 13. Psychiatr Genet 2004;14:83-87.

39 Altshuler D, Daly MJ, Lander ES: Genetic mapping in human disease. Science 2008;322: 881-888.

40 Ercan-Sencicek AG, Stillman AA, Ghosh AK, Bilguvar K, O’Roak BJ, Mason CE, et al: LHistidine decarboxylase and Tourette's syndrome. N Engl J Med 2010;362:1901-1988.

-41 Fernandez T, Yan WL, Hamburger S, Rapoport JL, Saunders AM, Schapiro M, et al: Apolipoprotein E alleles in childhood-onset schizophrenia. Am J Med Genet 1999;88:211213.

-42 Castellan Baldan L, Williams KA, Gallezot JD, Pogorelov V, Rapanelli M, Crowley M, et al: Histidine decarboxylase deficiency causes Tourette syndrome: parallel findings in humans and mice. Neuron 2014;81:77-90.

43 Rapanelli M, Frick LR, Pogorelov V, Ota KT, Abbasi E, Ohtsu H, et al: Dysregulated intracellular signaling in the striatum in a pathophysiologically grounded model of Tourette syndrome. Eur Neuropsychopharmacol 2014; 24:1896-1906.

-44 Xu M, Li L, Ohtsu H, Pittenger C: Histidine decarboxylase knockout mice, a genetic model of Tourette syndrome, show repetitive grooming after induced fear. Neurosci Lett 2015;595:50-53.

-45 Manolio TA, Collins FS, Cox NJ, Goldstein DB, Hindorff LA, Hunter DJ, et al: Finding the missing heritability of complex diseases. Nature 2009;461:747-753.

-46 Cruz C, Camarena B, King N, Paez F, Sidenberg D, de la Fuente JR, et al: Increased prevalence of the seven-repeat variant of the dopamine D4 receptor gene in patients with obsessive-compulsive disorder with tics. Neurosci Lett 1997;231:1-4.
47 Diaz-Anzaldua A, Joober R, Riviere JB, Dion Y, Lesperance P, Richer F, et al: Tourette syndrome and dopaminergic genes: a familybased association study in the French Canadian founder population. Mol Psychiatry 2004;9:272-277.

48 Grice DE, Leckman JF, Pauls DL, Kurlan R, Kidd KK, Pakstis AJ, et al: Linkage disequilibrium between an allele at the dopamine D4 receptor locus and Tourette syndrome, by the transmission-disequilibrium test. Am J Hum Genet 1996;59:644-652.

49 Herzberg I, Valencia-Duarte AV, Kay VA, White DJ, Muller H, Rivas IC, et al: Association of DRD2 variants and Gilles de la Tourette syndrome in a family-based sample from a South American population isolate. Psychiatr Genet 2010;20:179-183.

50 Tarnok Z, Ronai Z, Gervai J, Kereszturi E, Gadoros J, Sasvari-Szekely M, et al: Dopaminergic candidate genes in Tourette syndrome: association between tic severity and $3^{\prime}$ UTR polymorphism of the dopamine transporter gene. Am J Med Genet B Neuropsychiatr Genet 2007;144B:900-905.

51 Barr CL, Wigg KG, Zovko E, Sandor P, Tsui LC: No evidence for a major gene effect of the dopamine D4 receptor gene in the susceptibility to Gilles de la Tourette syndrome in five Canadian families. Am J Med Genet 1996;67: 301-305.

52 Chou IC, Tsai CH, Lee CC, Kuo HT, Hsu YA, Li CI, et al: Association analysis between Tourette's syndrome and dopamine D1 receptor gene in Taiwanese children. Psychiatr Genet 2004; 14:219-221.

53 Cavallini MC, Di Bella D, Catalano M, Bellodi L: An association study between 5-HTTLPR polymorphism, COMT polymorphism, and Tourette's syndrome. Psychiatry Res 2000;97: 93-100.

54 Yoon DY, Rippel CA, Kobets AJ, Morris CM, Lee JE, Williams PN, et al: Dopaminergic polymorphisms in Tourette syndrome: association with the DAT gene (SLC6A3). Am J Med Genet B Neuropsychiatr Genet 2007; 144B:605-610.

55 Brett PM, Curtis D, Robertson MM, Gurling HM: Exclusion of the 5-HT1A serotonin neuroreceptor and tryptophan oxygenase genes in a large British kindred multiply affected with Tourette's syndrome, chronic motor tics, and obsessive-compulsive behavior. Am J Psychiatry 1995;152:437-440.

56 Mössner R, Müller-Vahl KR, Döring N, Stuhrmann M: Role of the novel tryptophan hydroxylase-2 gene in Tourette syndrome. Mol Psychiatry 2007;12:617-619.

57 Xu C, Ozbay F, Wigg K, Shulman R, Tahir E, Yazgan $\mathrm{Y}$, et al: Evaluation of the genes for the adrenergic receptors alpha $2 \mathrm{~A}$ and alpha $1 \mathrm{C}$ and Gilles de la Tourette syndrome. Am J Med Genet B Neuropsychiatr Genet 2003; 119B:54-59.
58 Bertelsen B, Melchior L, Jensen LR, Groth C, Glenthoj B, Rizzo R, et al: Intragenic deletions affecting two alternative transcripts of the IMMP2L gene in patients with Tourette syndrome. Eur J Hum Genet 2014;22:1283-1289.

59 Boghosian-Sell L, Comings DE, Overhauser J: Tourette syndrome in a pedigree with a $7 ; 18$ translocation: identification of a YAC spanning the translocation breakpoint at $18 \mathrm{q} 22.3$. Am J Hum Genet 1996;59:999-1005.

60 Cuker A, State MW, King RA, Davis N, Ward DC: Candidate locus for Gilles de la Tourette syndrome/obsessive compulsive disorder/ chronic tic disorder at 18q22. Am J Med Genet A $2004 ; 130$ A:37-39.

61 State MW, Greally JM, Cuker A, Bowers PN, Henegariu O, Morgan TM, et al: Epigenetic abnormalities associated with a chromosome 18(q21-q22) inversion and a Gilles de la Tourette syndrome phenotype. Proc Natl Acad Sci USA 2003;100:4684-4689.

62 Verkerk AJ, Mathews CA, Joosse M, Eussen $\mathrm{BH}$, Heutink P, Oostra BA, et al: CNTNAP2 is disrupted in a family with Gilles de la Tourette syndrome and obsessive compulsive disorder. Genomics 2003;82:1-9.

63 Belloso JM, Bache I, Guitart M, Caballin MR, Halgren C, Kirchhoff M, et al: Disruption of the CNTNAP2 gene in a $t(7 ; 15)$ translocation family without symptoms of Gilles de la Tourette syndrome. Eur J Hum Genet 2007;15: 711-713.

-64 Rodenas-Cuadrado P, Ho J, Vernes SC: Shining a light on CNTNAP2: complex functions to complex disorders. Eur J Hum Genet 2014; 22:171-178.

65 Lawson-Yuen A, Saldivar JS, Sommer S, Picker J: Familial deletion within NLGN4 associated with autism and Tourette syndrome. Eur J Hum Genet 2008;16:614-618.

-66 Jamain S, Quach H, Betancur C, Rastam M, Colineaux C, Gillberg IC, et al: Mutations of the $\mathrm{X}$-linked genes encoding neuroligins NLGN3 and NLGN4 are associated with autism. Nat Genet 2003;34:27-29.

67 Singh SK, Eroglu C: Neuroligins provide molecular links between syndromic and nonsyndromic autism. Sci Signal 2013;6:re4.

68 Prontera P, Napolioni V, Ottaviani V, Rogaia D, Fusco C, Augello B, et al: DPP6 gene disruption in a family with Gilles de la Tourette syndrome. Neurogenetics 2014;15:237242.

-69 Abelson JF, Kwan KY, O’Roak BJ, Baek DY, Stillman AA, Morgan TM, et al: Sequence variants in SLITRK1 are associated with Tourette's syndrome. Science 2005;310:317-320.

70 O'Roak BJ, Morgan TM, Fishman DO, Saus E, Alonso P, Gratacos M, et al: Additional support for the association of SLITRK1 var321 and Tourette syndrome. Mol Psychiatry 2010;15:447-450.

71 Deng H, Le WD, Xie WJ, Jankovic J: Examination of the SLITRK1 gene in Caucasian patients with Tourette syndrome. Acta Neurol Scand 2006; 114:400-402. 
72 Chou IC, Wan L, Liu SC, Tsai CH, Tsai FJ: Association of the Slit and Trk-like 1 gene in Taiwanese patients with Tourette syndrome. Pediatr Neurol 2007;37:404-406.

-73 Zimprich A, Hatala K, Riederer F, Stogmann E, Aschauer HN, Stamenkovic M: Sequence analysis of the complete SLITRK1 gene in Austrian patients with Tourette's disorder. Psychiatr Genet 2008;18:308309.

74 Scharf JM, Moorjani P, Fagerness J, Platko JV, Illmann C, Galloway B, et al: Lack of association between SLITRK1var321 and Tourette syndrome in a large family-based sample. Neurology 2008;70:1495-1496.

$\rightarrow 75$ Keen-Kim D, Mathews CA, Reus VI, Lowe TL, Herrera LD, Budman CL, et al: Overrepresentation of rare variants in a specific ethnic group may confuse interpretation of association analyses. Hum Mol Genet 2006; 15:33243328.

76 Miranda DM, Wigg K, Kabia EM, Feng Y, Sandor P, Barr CL: Association of SLITRK1 to Gilles de la Tourette syndrome. Am J Med Genet B Neuropsychiatr Genet 2009; 150B:483-486.

-77 Karagiannidis I, Rizzo R, Tarnok Z, Wolanczyk T, Hebebrand J, Nöthen MM, et al: Replication of association between a SLITRK1 haplotype and Tourette syndrome in a large sample of families. Mol Psychiatry 2012;17: 665-668.

-78 Zuchner S, Cuccaro M, Tran-Viet K, Cope H, Krishnan R, Pericak-Vance M, et al: SLITRK1 mutations in trichotillomania. Mol Psychiatry 2006;11:887-889.

-79 Stillman AA, Krsnik Z, Sun J, Rasin MR, State MW, Sestan N, et al: Developmentally regulated and evolutionarily conserved expression of SLITRK1 in brain circuits implicated in Tourette syndrome. J Comp Neurol 2009;513: 21-37.

80 Katayama K, Yamada K, Ornthanalai VG, Inoue T, Ota M, Murphy NP, et al: Slitrk1-deficient mice display elevated anxiety-like behavior and noradrenergic abnormalities. Mol Psychiatry 2010;15:177-184.

81 Ragoussis J: Genotyping technologies for genetic research. Annu Rev Genomics Hum Genet 2009;10:117-133.

82 Lee SH, Wray NR, Goddard ME, Visscher PM: Estimating missing heritability for disease from genome-wide association studies. Am J Hum Genet 2011;88:294-305.

-83 Scharf JM, Yu D, Mathews CA, Neale BM, Stewart SE, Fagerness JA, et al: Genome-wide association study of Tourette's syndrome. Mol Psychiatry 2013;18:721-728.

84 Paschou P, Yu D, Gerber G, Evans P, Tsetsos F, Davis LK, et al: Genetic association signal near NTN4 in Tourette syndrome. Ann Neurol 2014;76:310-315.

-85 Conrad DF, Pinto D, Redon R, Feuk L, Gokcumen $\mathrm{O}$, Zhang Y, et al: Origins and functional impact of copy number variation in the human genome. Nature 2010;464:704-712.
6 Redon R, Ishikawa S, Fitch KR, Feuk L, Perry $\mathrm{GH}$, Andrews TD, et al: Global variation in copy number in the human genome. Nature 2006;444:444-454.

87 Sebat J, Lakshmi B, Troge J, Alexander J, Young J, Lundin P, et al: Large-scale copy number polymorphism in the human genome. Science 2004;305:525-528.

88 Sundaram SK, Huq AM, Wilson BJ, Chugani HT: Tourette syndrome is associated with recurrent exonic copy number variants. Neurology 2010;74:1583-1590.

89 Nag A, Bochukova EG, Kremeyer B, Campbell DD, Muller H, Valencia-Duarte AV, et al: $\mathrm{CNV}$ analysis in Tourette syndrome implicates large genomic rearrangements in COL8A1 and NRXN1. PLoS One 2013; 8:e59061.

90 Fernandez TV, Sanders SJ, Yurkiewicz IR, Ercan-Sencicek AG, Kim YS, Fishman DO, et al: Rare copy number variants in Tourette syndrome disrupt genes in histaminergic pathways and overlap with autism. Biol Psychiatry 2012;71:392-402.

91 McGrath LM, Yu D, Marshall C, Davis LK, Thiruvahindrapuram B, Li B, et al: Copy number variation in obsessive-compulsive disorder and Tourette syndrome: a cross-disorder study. J Am Acad Child Adolesc Psychiatry 2014;53:910-919.

92 Sundaram SK, Huq AM, Sun Z, Yu W, Bennett L, Wilson BJ, et al: Exome sequencing of a pedigree with Tourette syndrome or chronic tic disorder. Ann Neurol 2011;69:901-904.

-93 Hooper SD, Johansson AC, Tellgren-Roth C, Stattin EL, Dahl N, Cavelier L, et al: Genome-wide sequencing for the identification of rearrangements associated with Tourette syndrome and obsessive-compulsive disorder. BMC Med Genet 2012;13:123.

94 Leckman JF, Peterson BS, Anderson GM, Arnsten AF, Pauls DL, Cohen DJ: Pathogenesis of Tourette's syndrome. J Child Psychol Psychiatry 1997;38:119-142.

95 Singer HS, Minzer K: Neurobiology of Tourette's syndrome: concepts of neuroanatomic localization and neurochemical abnormalities. Brain Dev 2003;25(suppl 1):S70-S84.

96 Kataoka Y, Kalanithi PS, Grantz H, Schwartz ML, Saper C, Leckman JF, et al: Decreased number of parvalbumin and cholinergic interneurons in the striatum of individuals with Tourette syndrome. J Comp Neurol 2010;518: 277-291.

97 Singer HS, Hahn IH, Moran TH: Abnormal dopamine uptake sites in postmortem striatum from patients with Tourette's syndrome. Ann Neurol 1991;30:558-562.

98 Lerner A, Bagic A, Simmons JM, Mari Z, Bonne $\mathrm{O}, \mathrm{Xu} \mathrm{B}$, et al: Widespread abnormality of the gamma-aminobutyric acid-ergic system in Tourette syndrome. Brain 2012;135:19261936.
\$9 Xu M, Kobets A, Du JC, Lennington J, Li L, Banasr M, et al: Targeted ablation of cholinergic interneurons in the dorsolateral striatum produces behavioral manifestations of Tourette syndrome. Proc Natl Acad Sci USA 2015;112:893-898.

100 Jeffries KJ, Schooler C, Schoenbach C, Herscovitch P, Chase TN, Braun AR: The functional neuroanatomy of Tourette's syndrome: an FDG PET study III: functional coupling of regional cerebral metabolic rates. Neuropsychopharmacology 2002;27: 92-104.

101 Singer HS, Szymanski S, Giuliano J, Yokoi F, Dogan AS, Brasic JR, et al: Elevated intrasynaptic dopamine release in Tourette's syndrome measured by PET. Am J Psychiatry 2002;159:1329-1336.

102 Leckman JF, Goodman WK, Anderson GM, Riddle MA, Chappell PB, McSwiggan-Hardin MT, et al: Cerebrospinal fluid biogenic amines in obsessive compulsive disorder, Tourette's syndrome, and healthy controls. Neuropsychopharmacology $1995 ; 12: 73-$ 86.

103 Comings DE, Comings BG, Muhleman D, Dietz G, Shahbahrami B, Tast D, et al: The dopamine D2 receptor locus as a modifying gene in neuropsychiatric disorders. JAMA 1991;266:1793-1800.

104 Wong DF, Brasic JR, Singer HS, Schretlen DJ, Kuwabara H, Zhou Y, et al: Mechanisms of dopaminergic and serotonergic neurotransmission in Tourette syndrome: clues from an in vivo neurochemistry study with PET. Neuropsychopharmacology 2008;33: 1239-1251.

105 Anderson GM, Pollak ES, Chatterjee D, Leckman JF, Riddle MA, Cohen DJ: Brain monoamines and amino acids in Gilles de la Tourette's syndrome: a preliminary study of subcortical regions. Arch Gen Psychiatry 1992;49:584-586.

106 Lee CC, Chou IC, Tsai CH, Wang TR, Li TC, Tsai FJ: Dopamine receptor D2 gene polymorphisms are associated in Taiwanese children with Tourette syndrome. Pediatr Neurol 2005;33:272-276.

107 Gelernter J, Pauls DL, Leckman J, Kidd KK, Kurlan R: D2 dopamine receptor alleles do not influence severity of Tourette's syndrome. Results from four large kindreds. Arch Neurol 1994;51:397-400.

108 Nothen MM, Hebebrand J, Knapp M, Hebebrand K, Camps A, von Gontard A, et al: Association analysis of the dopamine D2 receptor gene in Tourette's syndrome using the haplotype relative risk method. Am J Med Genet 1994;54:249-252.

109 Comings DE, Wu S, Chiu C, Ring RH, Gade $\mathrm{R}$, Ahn C, et al: Polygenic inheritance of Tourette syndrome, stuttering, attention deficit hyperactivity, conduct, and oppositional defiant disorder: the additive and subtractive effect of the three dopaminergic genes - DRD2, D beta $\mathrm{H}$, and DAT1. Am J Med Genet 1996;67:264-288. 
110 Walther DJ, Peter JU, Bashammakh S, Hortnagl H, Voits M, Fink H, et al: Synthesis of serotonin by a second tryptophan hydroxylase isoform. Science 2003;299:76.

111 Guo Y, Su L, Zhang J, Lei J, Deng X, Xu H, et al: Analysis of the BTBD9 and HTR2C variants in Chinese Han patients with Tourette syndrome. Psychiatr Genet 2012;22:300-303.

-112 Dehning S, Muller N, Matz J, Bender A, Kerle I, Benninghoff J, et al: A genetic variant of HTR2C may play a role in the manifestation of Tourette syndrome. Psychiatr Genet 2010;20:35-38.

113 Liu SG, Zhang XH, Yin YY, Wang MJ, Che FY, Ma X: An association analysis between 5-HTTLPR polymorphism and obsessivecompulsive disorder, Tourette syndrome in a Chinese Han population. CNS Neurosci Ther 2011;17:793-795.

114 Moya PR, Wendland JR, Rubenstein LM, Timpano KR, Heiman GA, Tischfield JA, et al: Common and rare alleles of the serotonin transporter gene, SLC6A4, associated with Tourette's disorder. Mov Disord 2013;28: 1263-1270.
115 Arnold PD, Sicard T, Burroughs E, Richter MA, Kennedy JL: Glutamate transporter gene SLC1A1 associated with obsessivecompulsive disorder. Arch Gen Psychiatry 2006;63:769-776.

116 Adamczyk A, Gause CD, Sattler R, Vidensky S, Rothstein JD, Singer H, Wang T: Genetic and functional studies of a missense variant in a glutamate transporter, SLC1A3, in Tourette syndrome. Psychiatr Genet 2011;21: 90-97.

-117 Crane J, Fagerness J, Osiecki L, Gunnell B, Stewart SE, Pauls DL, et al: Family-based genetic association study of DLGAP3 in Tourette syndrome. Am J Med Genet B Neuropsychiatr Genet 2011;156B:108-114.

118 Welch JM, Lu J, Rodriguiz RM, Trotta NC, Peca J, Ding JD, et al: Cortico-striatal synaptic defects and OCD-like behaviours in $\mathrm{Sa}$ pap3-mutant mice. Nature 2007;448:894900.

119 Wan Y, Ade KK, Caffall Z, Ilcim Ozlu M, Eroglu C, Feng G, et al: Circuit-selective striatal synaptic dysfunction in the Sapap3 knockout mouse model of obsessive-compulsive disorder. Biol Psychiatry 2014;75: 623-630.
120 Ohtsu $\mathrm{H}$, Watanabe T: New functions of histamine found in histidine decarboxylase gene knockout mice. Biochem Biophys Res Commun 2003;305:443-447.

121 Ohtsu H, Tanaka S, Terui T, Hori Y, Makabe-Kobayashi Y, Pejler G, et al: Mice lacking histidine decarboxylase exhibit abnormal mast cells. FEBS Lett 2001;502:53-56.

122 Dietrich A, Fernandez TV, King RA, State MW, Tischfield JA, Hoekstra PJ, et al: The Tourette International Collaborative Genetics (TIC Genetics) study, finding the genes causing Tourette syndrome: objectives and methods. Eur Child Adolesc Psychiatry 2015;24:141-151.

123 Hoekstra PJ, Dietrich A: Tourette syndrome research in Europe has entered a new era of collaboration. Eur Child Adolesc Psychiatry 2015;24:125-126.

124 Pauls DL, Fernandez TV, Mathews CA, State MW, Scharf JM: The inheritance of Tourette disorder: a review. J Obsessive Compuls Relat Disord 2014;3:380-385. 